\title{
The impact of CG on the earnings quality of enterprises listed on the stock market in Vietnam
}

\author{
$\mathrm{Vu}$ Thi Thuy Van \\ National Economics University, \\ Vietnam \\ thuyvan@gmail.com
}

\author{
Dang Ngoc Hung \\ Hanoi University of Industry, Viet- \\ nam \\ hungdangngockt@yahoo.com.vn
}

\author{
Do Thi Thu Thuy \\ National Economics University, \\ Vietnam \\ thuydtt3108@gmail.com
}

\begin{abstract}
The paper examines the influence of corporate governance (CG) on the earnings quality (EQ) of listed companies in Vietnam. We consider the issue of CG integrated from each component of the board and the supervisory board using the GLS regression. The data are collected at energy enterprises listed on the Vietnam stock market in 2010 - 2018, with 2162 observations. The research results have found that the board positively impacts the EQ, while the supervisory board does not affect the earnings quality. Besides the audit quality, the ratio of liabilities positively affects the EQ; in contrast to the percentage of state ownership, the company's size has an opposite effect. In addition, foreign ownership ratio, profitability do not affect the $E Q$. The empirical research results are a valuable basis to help companies improve the EQ, thereby helping companies consider the elements of the board and supervisory more effectively for each company.
\end{abstract}

Index Terms-Corporate governance, Board of Directors, Supervisory Board; Earnings management; Earnings quality.

\section{INTRODUCTION}

$\mathrm{F}$ INANCIAL statements play an essential role in providing information about the performance of a business [33]. Meanwhile, information in financial statements depends on the quality of the firm's earnings [7]. Therefore, the quality of information about earnings has increasingly attracted the attention of many studies worldwide [17]. One of the critical factors affecting earnings quality is CG, including individual characteristics and representative factors.

There are many studies about this topic, such as [34], [32], [46]. The results are quite different when assessing the impact of the company's board of directors (BD) and the supervisory board on the quality of profits. The independent member of BD in [46], [18], [25] increases quality of profit, while this characteristic has no impact on EQ in [35], [22], [42], [9],[10]. The board size is positively related to EQ, such as [4], contrary to the research [24], the board size. However, in the study of [9], the board size does not affect the EQ. Thus, the heterogeneous results among the authors made it difficult to conclude, assess the impact of CG on the EQ, and cause many difficulties when using grounded theory in the interpretation. Several studies have examined this effect using aggregated indicators rather than individual factors such as [8], [30], [11], [12], [14], [29], [28], [43]. Based on that approach, this paper also examines the impact of CG on the quality of earnings in Vietnam.

\section{Literature Review}

[15] reviewed the EQ measurement method based on (1) company characteristics, (2) accounting methods, (3) CG and internal controls, (4) auditing, ( 5) market dynamics, and (6) external factors.

[38] measured EQ of listed companies through EM level. The author evaluates the factors affecting EQ related to the characteristics of BD. In addition, the study also analyzes the influence of control variables such as company size, financial leverage. Another study in Malaysia by [39] examined the relationship between audit firm size, internal audit setting, audit fee, firm size, number of subsidiaries, number of auditor certificates, corporate audit partners, and audit delay with the quality of financial statements. The selected sample size includes 113 companies listed on the Malaysian stock exchange. The authors also used a cross-sectional adjusted Jones model to measure EQ. [5] studied the influence of board independence on EQ. The results show that only the audit firm type factor does not affect EQ. In addition, the impact of $\mathrm{CG}$ on EQ through earnings management (EM) was carried out by [2], in the Arab country; [45] in Kenyan in Africa; [3] at the Bursa Malaysia stock exchange; [6] in Turkey. In Nigeria, [25] showed that financial leverage, BD, ownership ratio of the organization, size, independence, and several meetings positively influence EQ. Meanwhile, managers' ownership rates hurt EQ.

In individual studies on how CG effects EQ, research results worldwide are not uniform. On the plus side, earnings quality can fluctuate with board size. The reason is that a more significant number of board members with financial management experience can better supervise and control management activities [34], [46]. In the negative direction, the size of BD and the control of financial information will fluctuate in the opposite direction because the timely transmission of information between the directors and $\mathrm{BD}$ will be costly and time-consuming. In addition, the differing and sometimes contradictory opinions of a large BD can lead them to misrepresent their financial statements [1].

Independent members of $\mathrm{BD}$ play an essential role in monitoring management activities and contribute to making important decisions of the enterprise, thereby protecting the interests of shareholders [46], [37]. Meanwhile, it can be more challenging to ensure the quality of profits because they have less information about its specific activities. The supervision of independent members of BD has not been promoted optimally [36]. In addition, financial information can be manipulated in cases where power is concentrated too much on one subject [41]. However, this does not always hurt the EQ. [21] examined and concluded that some companies tend to have the Chairman of BD concurrently the Gen- 
eral Director because that will avoid conflicting operating and managing problems.

In addition to research on $\mathrm{CG}$ by individual components affecting the earnings quality by each aspect, there are also some studies using integrated CG [8]. The author studies non-financial companies in the US. The study results of individual factors in the multivariable regression equation, the size of BD, and the independent members have a negative relationship with the income management behavior or the members of $\mathrm{BD}$. The more independent members, the better the monitoring effect reduces earnings management. The remaining variables: number of meetings, activities of independent members, qualifications of independent members have no impact on earnings management behavior. The general factor representing CG and EQ has a negative relationship. At the same time, the results also acknowledge that combining the supervisory in the effective board reduces earnings management behavior. This study also suggests that it is advisable to consider the aggregate factor when studying $C G$ and earnings management and build good CG practices that contribute to earnings management behavior. [25] conducted this study to examine the impact of CG on earnings management behavior in enterprises with a sample of 60 observations in the 2008-2010 period in the Nigerian stock market. The regression results of the multivariate model demonstrated that only two CG representative influences the specific earnings management: the proportion of independent members has a negative correlation with the earnings management at the $1 \%$ significance level, meaning the more independent members, the higher the ability to monitor the activities of the managers, limiting earnings management behavior.

EQ has also been measured in many different ways. Each study often focuses on CG, company characteristics, and heterogeneous results. In emerging economies, studying the impact of CG on EQ is often considered on many factors due to differences in markets and economic structures.

\section{Model and Research Method}

\section{A. Model}

Based on the literature reviews, the proposed research model is as follows:

Earning quality ${ }_{i, t}=\beta_{0}+\beta_{1} B_{i, t}+\beta_{2} A_{i, t}+\beta_{3}$ STATEO $_{i, t}+$ $\beta_{4}$ FOREIGO $_{\mathrm{i}, \mathrm{t}}+\beta_{5}$ BIG4 $_{\mathrm{i}, \mathrm{t}}+\beta_{6}$ SIZE $_{\mathrm{i}, \mathrm{t}}+\beta_{7}$ LEV $_{\mathrm{i}, \mathrm{t}}+\beta_{8}$ ROA $\mathrm{i}, \mathrm{t}+\varepsilon_{\mathrm{i}, \mathrm{t}}$

The EQ measurement is based on the quality of the accruals [16]:

$$
\frac{W C A_{i t}}{A_{i t-1}}=\alpha_{1} \frac{C F O_{i t-1}}{A_{i t-1}}+\alpha_{2} \frac{C F O_{i t}}{A_{i t-1}}+\alpha_{3} \frac{C F O_{i t+1}}{A_{i t-1}}
$$

In which, $W C A_{i t}$ is the accumulated working capital of enterprise $\mathrm{i}$ in year $\mathrm{t}$; $\mathrm{CFO}_{i t-1} \mathrm{CFO}_{i t}, \mathrm{CFO}_{i t+1}$ are operating cash flows.

From equation (2), the model's residuals are used to measure EQ. Table 1 explains variables more clearly.
TABLE I

VARIABLES IN THE Model

\begin{tabular}{|c|c|c|c|}
\hline Variables & $\begin{array}{ll}\text { Name } & \text { of } \\
\text { variables } & \\
\end{array}$ & Measures & $\begin{array}{l}\text { Expectatio } \\
\text { ns }\end{array}$ \\
\hline EQ & $\begin{array}{l}\text { Earning } \\
\text { quality }\end{array}$ & $\begin{array}{l}\text { The absolute residual va- } \\
\text { lue of the model estima- } \\
\text { tes the cumulative qua- } \\
\text { lity multiplied by }(-1) \text {. } \\
\text { CACC }_{\text {it }}=\alpha+\beta_{1} \mathrm{CFO}_{\text {it- } 1}+ \\
\beta_{2} \mathrm{CFO}_{\text {it }}+\beta_{3} \mathrm{CFO}{ }_{\mathrm{it}+1}+ \\
\varepsilon_{\mathrm{it}}\end{array}$ & \\
\hline \multicolumn{4}{|l|}{ BD } \\
\hline BSIZE & Board Size & $\begin{array}{l}\text { BSIZE equals one if the } \\
\text { size is larger than the } \\
\text { median. }\end{array}$ & \\
\hline BIND & $\begin{array}{l}\text { The } \\
\text { independence } \\
\text { of the board }\end{array}$ & $\begin{array}{l}\text { BIND equal one if the } \\
\text { proportion of indepen- } \\
\text { dent members is more } \\
\text { significant than the } \\
\text { median }\end{array}$ & \\
\hline BMEET & $\begin{array}{l}\text { Meeting } \\
\text { frequency of } \\
\text { the board }\end{array}$ & $\begin{array}{l}\text { BMEET is one if the } \\
\text { number of meetings in } \\
\text { the company is greater } \\
\text { than the median }\end{array}$ & \\
\hline $\begin{array}{l}\text { CEODU } \\
\text { AL }\end{array}$ & $\begin{array}{l}\text { A plurality of } \\
\text { the board }\end{array}$ & Dummy variables & \\
\hline \multicolumn{4}{|l|}{$\mathbf{A C}$} \\
\hline ACSIZE & $\begin{array}{l}\text { Supervisory } \\
\text { board size }\end{array}$ & $\begin{array}{l}\text { ACSIZE is one if there } \\
\text { are at least } 3 \text { or } 4 \text { mem- } \\
\text { bers }\end{array}$ & \\
\hline ACEXP & $\begin{array}{l}\text { Financial } \\
\text { expertise of } \\
\text { the } \\
\text { supervisory } \\
\text { board }\end{array}$ & $\begin{array}{l}\text { ACEXP is one if the } \\
\text { supervisory has one } \\
\text { member with expertise } \\
\text { in finance and accoun- } \\
\text { ting. }\end{array}$ & \\
\hline ACMEET & $\begin{array}{l}\text { Frequency of } \\
\text { meetings of } \\
\text { the } \\
\text { Supervisory } \\
\text { Board }\end{array}$ & $\begin{array}{l}\text { ACMEET is } 1 \text { if the } \\
\text { number of meetings is } \\
\text { greater than the median }\end{array}$ & \\
\hline STATEO & $\begin{array}{l}\text { State } \\
\text { ownership }\end{array}$ & & - \\
\hline $\begin{array}{l}\text { FOREIG } \\
\text { O }\end{array}$ & $\begin{array}{l}\text { Foreign } \\
\text { ownership }\end{array}$ & & + \\
\hline BIG4 & $\begin{array}{l}\text { Auditing firm } \\
\text { size }\end{array}$ & Dummy variable & + \\
\hline SIZE & Firm size & $\begin{array}{l}\text { Log base } 10 \text { of total as- } \\
\text { sets }\end{array}$ & + \\
\hline LEV & Debt ratio & $\begin{array}{l}\text { Total liabilities / Total } \\
\text { assets }\end{array}$ & + \\
\hline ROA & Profitability & $\begin{array}{l}\text { Profit after tax / Total as- } \\
\text { sets }\end{array}$ & + \\
\hline
\end{tabular}

Source: Summary of the authors

\section{B. Research Method}

The study uses listed companies in Vietnam with 2162 observations in 2010-2018. The model uses the GLS method.

\section{Results and Discussion}

Also, according to Table II, the mean of the supervisory board members is 2.96 , the highest is 5 , and the lowest is 1 . The average ratio of the members is financial, accounting at 15.8. \%. The average number of meetings is 3,689 , and the lowest is 1 , and 65 is the highest. The average female member in the supervisory board is $52.3 \%$.

Table III shows the difference in the performance of listed companies. Some enterprises have low performance due to a lack of necessary CG characteristics. The supervisory Board (AC) variable is a composite variable representing all the individual factors representing the performance of $\mathrm{AC}$, includ- 
TABLE II

Descriptive STATISTICS OF CG CHARACTERISTICS

\begin{tabular}{llllll}
\hline Variable & Obs & Mean & Std.Dev & Min & Max \\
\hline BOARDSIZE & 2162 & 5.558 & 1.330 & 3 & 12 \\
BOARDIND & 2162 & 0.682 & 0.171 & 0.2 & 1 \\
BOARMEET & 2162 & 10.142 & 9.816 & 1 & 78 \\
BOARDDUAL & 2162 & 0.243 & 0.429 & 0 & 1 \\
BOARDGENR & 2162 & 0.158 & 0.179 & 0 & 1 \\
AUDITCSIZE & 2162 & 2.962 & 0.449 & 1 & 5 \\
AUDITCEXP & 2162 & 0.158 & 0.242 & 0 & 1 \\
AUDITCMEET & 2162 & 3.685 & 4.404 & 1 & 65 \\
AUDITCGENR & 2162 & 0.523 & 0.312 & 0 & 1 \\
\hline Source: Author calculated from Stata 14.0 & &
\end{tabular}

ing the complex components: the size, the financial expertise, accounting of the members, the number of times the board of controllers meets, the percentage of female members of controllers. The average value of AC reaches 2,085, with the standard deviation being 1,140 . For control variables, the average State ownership is $24.6 \%$, the average foreign ownership is $10.3 \%, 25.3 \%$ of enterprises are audited by an audit firm of Big4, the size of according to the average, after logarithm, the enterprise by assets is 11,749 , the average ratio of liabilities to total assets is $50.5 \%$, and the ratio of profit after tax to total assets (ROA) is $5.8 \%$.

TABLE III

STATISTICS DESCRIBING VARIABLES IN THE RESEARCH MODEL

\begin{tabular}{llllll}
\hline Variable & Obs & Mean & Std.Dev & Min & Max \\
\hline EQ & 2162 & -0.087 & 0.100 & -0.914 & 0 \\
BD & 2162 & 2.537 & 1.153 & 0 & 5 \\
AC & 2162 & 2.085 & 1.140 & 0 & 4 \\
STATEO & 2162 & 0.246 & 0.237 & 0 & 0.910 \\
FOREIGO & 2162 & 0.103 & 0.137 & 0 & 0.780 \\
BIG4 & 2162 & 0.253 & 0.435 & 0 & 1 \\
SIZE & 2162 & 11.749 & 0.694 & 10.132 & 14.459 \\
& & & & & \\
LEV & 2162 & 0.505 & 0.212 & 0.012 & 0.993 \\
ROA & 2162 & 0.058 & 0.077 & -0.853 & 0.784 \\
\hline
\end{tabular}

In the autocorrelation matrix, it can be seen that the variable $\mathrm{BD}$ is positively correlated with the EQ. In contrast, the variable AC is positively correlated with EQ. The correlation coefficient between the independent variables in the model with no pair is more significant than 0.8 , so there is a slight possibility of multicollinearity.

In Table V, BD and EQ have a positive relationship. This result supports the theory that $\mathrm{BD}^{\prime}$ effectiveness reduces conflicts between owners and managers, consistent with the findings of [8]. According to agency theory, BD plays a massive role in monitoring the behavior of managers and resolving conflicts of interest.
TABLE IV

CORRELATION MATRIX

\begin{tabular}{|c|c|c|c|c|c|c|c|c|c|}
\hline & EQ & BD & $\mathbf{A C}$ & $\begin{array}{l}\text { STATE } \\
\text { O }\end{array}$ & $\begin{array}{l}\text { FOR } \\
\text { EIGO }\end{array}$ & $\begin{array}{l}\text { BI } \\
\text { G4 } \\
\end{array}$ & $\begin{array}{l}\text { SI } \\
\text { ZE }\end{array}$ & $\begin{array}{l}\text { LE } \\
\mathbf{V}\end{array}$ & $\begin{array}{l}\mathbf{R} \\
\mathbf{O} \\
\mathbf{A}\end{array}$ \\
\hline EQ & $\begin{array}{l}1 \\
0.0\end{array}$ & & & & & & & & \\
\hline BD & $\begin{array}{l}35 \\
- \\
0.0\end{array}$ & $\begin{array}{l}1 \\
0.1\end{array}$ & & & & & & & \\
\hline $\mathbf{A C}$ & $\begin{array}{l}49 \\
-\end{array}$ & $\begin{array}{l}19 \\
-\end{array}$ & 1 & & & & & & \\
\hline $\begin{array}{l}\text { STAT } \\
\text { EO }\end{array}$ & $\begin{array}{l}0.1 \\
12 \\
-\end{array}$ & $\begin{array}{l}0.0 \\
98\end{array}$ & $\begin{array}{l}0.0 \\
39\end{array}$ & $\begin{array}{l}1 \\
-\end{array}$ & & & & & \\
\hline FOR & 0.0 & 0.1 & 0.1 & 0.17 & & & & & \\
\hline EIGO & 50 & 73 & 34 & $\begin{array}{l}1 \\
-\end{array}$ & 1 & & & & \\
\hline BIG4 & $\begin{array}{l}0.0 \\
02 \\
- \\
0.0\end{array}$ & $\begin{array}{l}0.1 \\
73 \\
0.2\end{array}$ & $\begin{array}{l}0.1 \\
31 \\
0.1\end{array}$ & $\begin{array}{l}0.03 \\
7 \\
- \\
0.06\end{array}$ & 0.354 & 0.5 & & & \\
\hline SIZE & 98 & 32 & $\begin{array}{l}91 \\
-\end{array}$ & 6 & 0.377 & 21 & 1 & & \\
\hline LEV & $\begin{array}{l}0.0 \\
24 \\
- \\
0.0\end{array}$ & $\begin{array}{l}0.0 \\
12 \\
- \\
0.0\end{array}$ & $\begin{array}{l}0.1 \\
11 \\
0.0\end{array}$ & $\begin{array}{l}0.11 \\
5\end{array}$ & -0.152 & $\begin{array}{l}0.0 \\
23 \\
0.0\end{array}$ & $\begin{array}{l}0.3 \\
23 \\
- \\
0.0\end{array}$ & $\begin{array}{l}1 \\
- \\
0.3\end{array}$ & \\
\hline ROA & 49 & 41 & 86 & 8 & 0.118 & 73 & 24 & 84 & 1 \\
\hline
\end{tabular}

TABLE V

Regression Results

\begin{tabular}{|c|c|c|c|c|}
\hline & VIF & $\begin{array}{l}\text { FEM } \\
\text { model }\end{array}$ & $\begin{array}{l}\text { REM } \\
\text { model }\end{array}$ & $\begin{array}{l}\text { GLS } \\
\text { model }\end{array}$ \\
\hline $\mathrm{BD}$ & 1.09 & 0.00101 & $0.00465 *$ & $0.00458 * *$ \\
\hline $\mathrm{AC}$ & 1.09 & $-0.00833 *$ & -0.00162 & -0.00118 \\
\hline STATEO & 1.08 & -0.012 & $-0.0240 *$ & $-0.0543 * * *$ \\
\hline FOREIGO & 1.35 & $-0.142 * * *$ & $-0.128 * * *$ & -0.0218 \\
\hline BIG4 & 1.47 & -0.00649 & $0.0327 * * *$ & $0.0213 * * *$ \\
\hline SIZE & 1.93 & $-0.156 * * *$ & $-0.0812 * * *$ & $-0.0258 * * *$ \\
\hline LEV & 1.54 & $0.141 * * *$ & $0.101 * * *$ & $0.0387 * * *$ \\
\hline ROA & 1.21 & $0.122 * * *$ & $0.105^{* * *}$ & -0.0208 \\
\hline _cons & & $1.704 * * *$ & $0.812 * * *$ & $0.200 * * *$ \\
\hline $\mathrm{N}$ & & 2162 & 2162 & 2162 \\
\hline R-sq & & 0.214 & & \\
\hline \multirow{2}{*}{$F$ test } & & $\begin{array}{l}\mathrm{F}(8,1901)= \\
64.60\end{array}$ & & \\
\hline & & $\begin{array}{l}\text { Prob }>F= \\
0.0000\end{array}$ & & \\
\hline \multirow[t]{2}{*}{ LM test } & & & $\begin{array}{l}\text { Wald chi2(8) } \\
=302.94\end{array}$ & $\begin{array}{l}\text { Wald } \\
\text { chi2(8) = } \\
87.82\end{array}$ \\
\hline & & & $\begin{array}{l}\text { Prob }>\text { chi } 2= \\
0.0000\end{array}$ & $\begin{array}{l}\text { Prob }>\text { chi2 } \\
=0.0000\end{array}$ \\
\hline \multirow{2}{*}{$\begin{array}{l}\text { Hausman } \\
\text { test }\end{array}$} & \multicolumn{3}{|c|}{$\operatorname{chi} 2(8)=212.99$} & \\
\hline & & Prob $>$ chi $2=$ & 0.0000 & \\
\hline \multirow{2}{*}{$\begin{array}{l}\text { Modified } \\
\text { Wald test }\end{array}$} & & $\operatorname{chi} 2(253)=$ & $1.3 \mathrm{e}+06$ & \\
\hline & & Prob $>$ chi $2=$ & 0.0000 & \\
\hline $\begin{array}{l}\text { Wooldridge } \\
\text { test }\end{array}$ & & $\begin{array}{c}F(1,248)= \\
\text { Prob }>F=0\end{array}$ & $\begin{array}{l}876.437 \\
327\end{array}$ & \\
\hline
\end{tabular}

$\mathrm{t}$ statistics in brackets $* \mathrm{p}<0.1, * * \mathrm{p}<0.05, * * * \mathrm{p}<0.01$

Source: Author calculated from Stata 14.0 
Besides, BD meets the requirements to increase the effectiveness of supervisory activities, improve the quality of earnings; in other words, BD has a diversified structure and functions to increase the quality of earnings [27], [8].

Research results show that AC does not affect the change of income quality, so it is not consistent with the original expectation of the author. Thus, the results of this study do not support the agency theory, the resource dependency theory, which holds that the conflict of interest between managers and owners is controlled through activities.

State ownership (STATEO), according to the model regression results with the dependent variable of earnings quality with coefficient $=-0.0543$, with a $1 \%$ significance level, the STATEO variable harms the EQ, or companies with more state ownership, the lower the EQ. The research results support the author's expectations and the state-owned companies' implementation of many earnings management behaviors, leading to a decrease in the quality of corporate profits. This research result does not agree with the research result of [20].

Besides, the research results show that enterprises audited by Big4 audit firms increase income quality. This means that when the company has a large-scale audit, the reputation index of Big4 increases EQ. This result can be explained because Big4 companies have good professional teams, experience, and a strict audit process. The managers of the Big4 audited companies became more hesitant to implement earnings management, resulting in an increased quality of earnings. This result is also consistent with the study of [46].

The variable debt ratio (LEV), the regression result with the coefficient $=0.0387$ at the $1 \%$ significance level. This means that when a company has a higher liabilities ratio, it increases the earnings quality. Therefore, this research result is contrary to the views of [45], [40], [44], [13], [23].

\section{Conclusions}

The article has reviewed enterprises in Vietnam from 2010 to 2018 to assess the impact of CG on earnings quality. We have shown that the management of BD has a positive impact on the profitability of companies. Meanwhile, the general supervision did not affect the quality of the companies' profits. Control variables such as state ownership, audit quality (Big4), firm size, and financial leverage also affect EQ. Apart from the foreign ownership ratio, the profitability of companies does not affect EQ. On that basis, we propose some recommendations:

- The importance of CG needs to be clarified, especially the role of $\mathrm{BD}$ in the quality of profits. Enterprises need to build a CG model following the law. In which the structure of BD should meet the requirements.

- Information about the enterprise needs to be supplemented fully and clearly in CG activities. This will assist analysts and investors in evaluating businesses based on quantitative models.

- Companies should consider choosing large and reputable auditing units to ensure the best quality of the information provided. Besides, investors can rely on the audit company's information on the audited financial statements to determine the quality of profits on the figures of the financial statements, thereby making investment decisions.

\section{REFERENCES}

[1] Abdul Rahman, R., \& Haneem Mohamed Ali, F. (2006). Board, audit committee, culture and earnings management: Malaysian evidence. Managerial Auditing Journal, 21(7), 783-804. doi:https://doi.org/ $10.1108 / 02686900610680549$

[2] Abed, S., Al-Attar, A., \& Suwaidan, M. (2012). CG and earnings management: Jordanian evidence. International business research, 5(1), 216-225. doi:doi:10.5539/ibr.v5n1p216

[3] Ahmed, S. (2014). Board of director characteristics and earnings management in Malaysia. GSTF Journal on Business Review (GBR), 2(4), 94-99. doi: DOI: 10.5176/2010-4804_2.4.255

[4] Al-Othman, L. N., \& Al-Zoubi, M. N. (2019). The Impact of BD Characteristics on Earnings Quality of Listed Industrial Companies on the Amman Stock Exchange. Academy of Accounting and Financial Studies Journal, 23(1), 1-16.

[5] Alves, S. (2014). The effect of board independence on the earnings quality: evidence from portuguese listed companies. Australasian Accounting, Business and Finance Journal, 8(3), 23-44. doi:http://dx.doi.org/10.14453/aabfj.v8i3.3

[6] Aygun, M., Ic, S., \& Sayim, M. (2014). The Effects of corporate ownership structure and board size on earnings management: Evidence from Turkey. International Journal of Business and Management, 9(12), 123-132. doi:doi:10.5539/ijbm.v9n12p123

[7] Ball, R., \& Shivakumar, L. (2005). Earnings quality in UK private firms: comparative loss recognition timeliness. Journal of accounting and economics, 39(1), 83-128. doi:https://doi.org/10.1016/j.jacceco.2004.04.001

[8] Carcello, J. V., Hollingsworth, C. W., Klein, A., \& Neal, T. L. (2006). Audit committee financial expertise, competing CG mechanisms, and earnings management. Available at SSRN: https://ssrn.com/ abstract=887512 or. doi:http://dx.doi.org/10.2139/ssrn. 887512

[9] Chaharsoughi, M. T., \& Rahman, R. A. (2013). CG and earnings quality: the experience of listed companies in Iran. Journal of Modern Accounting and Auditing, 9(6), 790-797.

[10] Chalaki, P., Didar, H., \& Riahinezhad, M. (2012). CG attributes and financial reporting quality: Empirical evidence from Iran. International Journal of Business and Social Science, 3(15), 223-229.

[11] Dang, H. N., Nguyen, T. T. C., \& Tran, D. M. (2020). The Impact of Earnings Quality on Firm Value: The Case of Vietnam. The Journal of Asian Finance, Economics and Business (JAFEB), 7(3), 63-72.

[12] Dang, H. N., Pham, C. D., Nguyen, T. X., \& Nguyen, H. T. T. (2020). Effects of CG and Earning Quality on Listed Vietnamese Firm Value. The Journal of Asian Finance, Economics and Business (JAFEB), 7(4), 71-80.

[13] Dang, H. N., \& Tran, D. M. (2019). Relationship between Accrual Anomaly and Stock Return: The Case of Vietnam. The Journal of Asian Finance, Economics and Business, 6(4), 19-26.

[14] Dang Ngoc, H., Truong Thanh, H., Van Thuy, V. T., Nguyen Thi Thanh, L., Hoang Thi Viet, H., Nguyen Thi Lan, A., \& Nguyen Thi Hong, N. (2020). Accounting Conservatism and Cash Dividend Policy of Enterprises in Vietnam. Paper presented at the IFCAA 2020, Ha Noi, VietNam.

[15] Dechow, P., Ge, W., \& Schrand, C. (2010). Understanding earnings quality: A review of the proxies, their determinants and their consequences. Journal of accounting and economics, 50(2-3), 344-401. doi:https://doi.org/10.1016/j.jacceco.2010.09.001

[16] Dechow, P. M., \& Dichev, I. D. (2002). The quality of accruals and earnings: The role of accrual estimation errors. The Accounting Review, 77(s-1), 35-59. doi:https://doi.org/10.2308/accr.2002.77.s-1.35

[17] Dechow, P. M., Kothari, S. P., \& Watts, R. L. (1998). The relation between earnings and cash flows. Journal of accounting and economics, 25(2), 133-168. doi:https://doi.org/10.1016/S0165-4101(98)00020-2

[18] Ebrahim, A. (2007). Earnings management and board activity: an additional evidence. Review of Accounting and Finance, 6(1), 42-58. doi:https://doi.org/10.1108/14757700710725458

[19] Epstein, B. J., \& Jermakowicz, E. K. (2008). IFRS Policies and Procedures: John Wiley \& Sons.

[20] Essa, S., Kabir, R., \& Nguyen, H. T. (2016). Does CG affect earnings management? Evidence from Vietnam. Paper presented at the Vietnam symposium in Banking and Finance (VSBF).

[21] Finkelstein, S., \& D'aveni, R. A. (1994). CEO duality as a doubleedged sword: How boards of directors balance entrenchment avoidance and unity of command. Academy of management Journal, 37(5), 1079-1108. doi:https://doi.org/10.5465/256667

[22] Gulzar, M. A. (2011). CG characteristics and earnings management: Empirical evidence from Chinese listed firms. International Journal of 
Accounting and Financial Reporting, 1(1), 133-151. doi:DOI: 10.5296/ijafr.v1i1.854

[23] Ha, H. T. V., Van, V. T. T., \& Hung, D. N. (2019). Impact of Social Reponsibility Information Disclosure on the Financial Performance of Enterprises in Vietnam. Indian Journal of Finance, 13(1), 20-36. doi:10.17010/ijf/2019/v13i1/141017

[24] Hashim, H. A., \& Devi, S. (2008). Board characteristics, ownership structure and earnings quality: Malaysian evidence. Research in Accounting in Emerging Economies, 8(97), 97-123. doi: https://doi.org/ 10.1016/S1479-3563(08)08004-3

[25] Hassan, S. U., \& Ahmed, A. (2012). CG, earnings management and financial performance: A case of Nigerian manufacturing firms. American International Journal of Contemporary Research, 2(7), 214-226.

[26] Hassan, S. U., \& Bello, A. (2013). Firm characteristics and financial reporting quality of listed manufacturing firms in Nigeria. International Journal of Accounting, Banking and Management, 1(6), 47-63.

[27] Hoang, T. C., Abeysekera, I., \& Ma, S. (2018). Board diversity and corporate social disclosure: evidence from Vietnam. Journal of Business Ethics, 151(3), 833-852. doi:https://doi.org/10.1007/s10551-0163260-1

[28] Hung, D. N., \& Van, V. T. T. (2020a). Researching the Firm Characteristics Affecting the Earnings Quality: The Case of Vietnam. Calitatea, 21(179), 106-112.

[29] Hung, D. N., \& Van, V. T. T. (2020b). Studying the impacts of earnings quality on stock return: Experiments in Vietnam. International Journal of Advanced and Applied Sciences, 7, 45-53.

[30] Kang, H. H., \& Liu, S. B. (2014). Corporate social responsibility and corporate performance: a quantile regression approach. Quality \& Quantity, 48(6), 3311-3325.

[31] Kang, S.-A., \& Kim, Y.-S. (2012). Effect of CG on real activity-based earnings management: Evidence from Korea. Journal of Business Economics and Management, 13(1), 29-52. doi:10.3846/16111699. 2011.620164

[32] Klein, A. (2002). Audit committee, board of director characteristics, and earnings management. Journal of accounting and economics, 33(3), 375-400.

[33] Mackenzie, B., Coetsee, D., Njikizana, T., Chamboko, R., Colyvas, B., \& Hanekom, B. (2012). Wiley IFRS 2013: Interpretation and Application of International Financial Reporting Standards: John Wiley \& Sons.
[34] Marrakchi Chtourou, S., Bedard, J., \& Courteau, L. (2001). CG and earnings management. Available at SSRN: https://ssrn.com/ abstract=275053 1-35. doi:http://dx.doi.org/10.2139/ssrn.275053

[35] Murhadi, W. R. (2011). Good CG and earning management practices: An Indonesian cases. Jurnal Manajemen, 10(2), 143-155.

[36] Park, Y. W., \& Shin, H.-H. (2004). Board composition and earnings management in Canada. Journal of Corporate Finance, 10(3), 431-457.

[37] Peasnell, K. V., Pope, P. F., \& Young, S. (2005). Board monitoring and earnings management: Do outside directors influence abnormal accruals? Journal of Business Finance \& Accounting, 32(7-8), 13111346.

[38] Qinghua, W., Pingxin, W., \& Junming, Y. (2007). Audit committee, board characteristics and quality of fi nancial reporting: An empirical research on Chinese securities market. Frontiers of Business Research in China, 1(3), 385-400.

[39] Radzi, S., Islam, M. A., \& Ibrahim, S. (2011). Earning quality in public listed companies: A study on Malaysia exchange for securities dealing and automated quotation. International Journal of Economics and Finance, 3(2), 233-244.

[40] Rahmani, S., \& Akbari, M. A. (2013). Impact of firm size and capital structure on earnings management: evidence from Iran. World of Sciences Journal, 1(17), 59-71.

[41] Saleh, N. M., Iskandar, T. M., \& Rahmat, M. M. (2005). Earnings management and board characteristics: Evidence from Malaysia. Jurnal Pengurusan (UKM Journal of Management), 24.

[42] Soliman, M. M., \& Ragab, A. A. (2014). Audit committee effectiveness, audit quality and earnings management: an empirical study of the listed companies in Egypt. Research Journal of Finance and Accounting, 5(2), 155-166.

[43] Van Khanh, V. T., \& Hung, D. N. (2020). Impact of Earnings Quality on the Debt Maturity: The Case of Vietnam. Asian Economic and Financial Review, 10(1), 1-12.

[44] Van Linh, N., Hung, D. N., Dang, T. B., Van, V. T. T., \& Anh, N. T. M. (2019). The Effects of Business Efficiency to Disclose Information of Sustainable Development: The Case of Vietnam. Asian Economic and Financial Review, 9(4), 547-558.

[45] Waweru, N. M., \& Riro, G. K. (2013). CG, firm characteristics and earnings management in an emerging economy. Journal of Applied Management Accounting Research, 11(1), 43-64.

[46] Xie, B., Davidson, W. N., \& DaDalt, P. J. (2003). Earnings management and CG: the role of the board and the audit committee. Journal of Corporate Finance, 9(3), 295-316. 